\title{
Navorsingsartikels / Research articles \\ Godsdiensvryheid in 'n toekomstige Suid-Afrika in die lig van artikel 36 van die Nederlandse Geloofsbelydenis
}

\author{
J. M. Vorster \\ Dept. Ekklesiologie en Dogmatologie \\ $\mathrm{HTS} / \mathrm{PU}$ vir $\mathrm{CHO}$ \\ POTCHEFSTOOM
}

\begin{abstract}
Freedom of religion is a basic human right and is acknow'ledged as such in Christian ethics. The application of religious freedom may, however, not lead to a reduction of Christian faith and doctrine; it should also not result in a society with 'freedom from religion'. Christians should be able to manifest their religious beliefs in teaching, practice, worship, observance, missionary activity and evangelism.

This article explores practical ways in which the principle of freedom of religion can be applied in a future South Africa to meet the demands of Christians without being detrimental to other religions. Attention is paid to the preamble of a future constitution, education, prayers at public meetings, chaplain services and the use of state-controlled communication media. Proposals in this regard are formulated within the framework of Article 36 of the Belgic Confession which deals with the biblical point of view regarding civil authority and its responsibility.
\end{abstract}

\section{Inleiding}

Godsdienswryheid word tans wêreldwyd beskou as 'n basiese mensereg wat saam met ander regte beskerm moet word (Lendvai, 1983:7). Hierdie stand van sake is grootliks die gevolg van die Verenigde Volke Organisasie (VVO) se internasionale Deklarasie van Menseregte en verskeie besluite wat daarop rus. Artikel 18 van hierdie deklarasie lui:

Everyone has the right to freedom of thought, conscience and religion, this right includes freedom to change his religion or belief, and freedom either 
alone or in community with others, in public or private to manifest his religion or belief in teaching, practice, worship and observance (GES, 1983. 87).

Ook in Suid-Afrika is godsdiensvryheid in 'n groot mate erken en toegepas. Godsdienste bet die reg om openlik te funksioneer en eie strukture hiervoor te skep. In die huidige staatstrukture het die Christelike geloof tot nog toe meer prominensie ontvang, soos blyk uit die gebruik van en toegang tot staatsbeheerde media deur die onderskeie godsdienste. In die ontwikkeling van 'n handves van menseregte vir 'n toekomstige Suid-Afrika geniet die saak ook hoë prominensie en lê feitlik al die groot rolspelers in die onderhandelingsproses hierop klem. Die algemene standpunt word uitgedruk in die voorgestelde Handves van die SuidAfrikaanse Regskommissie. Oor godsdiensvryheid word die volgende in artikel 18 van die verslag gestel:

Elke persoon het die reg om afsonderlik of gesamentlik met andere die godsdiens en kultuur van sy of haar keuse vryelik te beoefen en die taal van sy of haar keuse vryelik te gebruik, wat inhou dat daar geen benadeling of bevoorregting van enige persoon toegepas mag word weens sy of haar godsdiens, kultuur of taal nie (Suid-Afrikaanse Regskommisssie, 1991:47).

Hierdie benadering het reeds gestalte gevind in die openingsgebede van Kodesa 1 en Kodesa 2 waar aan al die groot verteenwoordigende godsdienste in SuidAfrika geleentheid gegee is om vir hulle volgelinge ' $n$ gebed waar te neem as uitdrukking van godsdiensvryheid.

Ook die Christelike kerke het 'n meer soepel benadering teenoor ander godsdienste begin aanneem - in teenstelling met die radikale ontkenning van die openbare regte van ander godsdienste in die verlede. Runia (1990:341) wys daarop dat religieuse pluralisme al hoe meer ' $n$ werklikheid geword het in die hedendaagse wêreld as gevolg van die toename in internasionale toerisme, kommunikasie, die groei in religieuse studies aan universiteite en die migrasie van mense wêreldwyd. Tradisioneel Christelike gemeenskappe het al hoe meer in kontak gekom met die inhoud en aard van ander godsdienste. Kritzinger (1991:215) praat al van 'n teologie van godsdienste waaronder hy verstaan: "a theology for interfaith encounter". In Suid-Afrika het hierdie bewuswording gelei tot samewerking tussen Christene en ander godsdienste in đie National Inter-Faith Conference on Religion-State Relations wat gelei het tot 'n gesamentlike deklarasie vir godsdiensregte deur die World Religion and Peace Conference - South Africa (WRPC-SA, 1992:1).

Binne die kring van gereformeerde Kerke het die standpunt van die Gereformeerde Ekumeniese Sinode (GES - nou die Gereformeerde Ekumeniese Raad) oor godsdiensvryheid wye inslag gevind. $\mathrm{Na}$ 'n behandeling van die standpunte 
oor menseregte in die verskeie Christelike tradisies asook Bybelse perspektiewe oor menseregte sê die GES dat inenseregte die volgende inhou:

The right to freedom of worship - challenging us to intervene on behalf of persecuted worshipping communities, Christians and others, assuring them the opportunity to gather in their places of worship without molestation, discrimination or reprisal.

Die verklaring stel ook dat:

... the right to religious liberty - challenging us in a religiously pluralist world to plead the cause of all persons and communities to freely choose and change their religions, to live out their beliefs freely, both privately and publicly, within the various structures of society, without infringing upon the similar rights of others (GES, 1983:151).

Die Gereformeerde Kerke in Suid-Afrika het hierdie standpunte aanvaar (GKSA, 1985:651) terwyl die Nederduitse Gereformeerde Kerk die beginsel aanvaar (NGK, 1986:31).

Die algemene aanvaarding van die reg op godsdiensvryheid skep egter 'n probleem vir die gelowiges wat nog vashou aan artikel 36 van die Nederlandse Geloofsbelydenis. Hierdie artikel handel oor die owerheid en sy taak en stel dan onder andere in sy oorspronklike fornulering dat dit die taak van die owerheid is "om die heilige Woordbediening te beskern, om alle afgodery en valse godsdiens teen te gaan en uit te roei" (Polman, s.j.:284). Die vraag kan dus gestel hoe godsdiensvryheid rym met artikel 36 van die Nederlandse Geloofsbelydenis. Krämer (1981:13) vra byvoorbeeld of die uniekheid van die Christelike godsdiens in die erkenning van die reg van godsdiensvryheid nog volledig tot uiting kom. So kan ook gevra word hoe 'n toekomstige model vir godsdiensvryheid deur gereformeerdes in Suid-Afrika bejeën moet word

Om tot 'n duidelike standpuntinname hieroor te kom is dit nodig om aandag te gee aan die debat wat oor die beginsel en formulering van artikel 36 van die Nederlandse Geloofsbelydenis oor eeue in gereformeerde kringe gevoer is. Vir hierdie doel moet gelet word op die standpunt van Calvyn waarop die Nederlandse Geloofsbelydenis teologies rus en die hooflyne van kritiek wat daarteen ingebring is.

\section{Die standpunt van Calvyn}

Calvyn sê dat God die burgerlike regering ingestel het vanweë die realiteit van die sonde. Vanweè die 'die teuelloosheid' van sondige mens is wette en die toepassers van wette nodig. Volgens hom het die burgerlike regering dan die taak om in hierdie sondige bedeling die 'uiterlike godsdiens' te ondersteun en te beskerm, die gesonde leer van vroomheid en die kerk te verdedig, die menselewe 
in te rig tot ordelike samelewing, die sedes te vorm, mense met mekaar te verenig en die algemene rus en vrede te voed (Calvyn, 1949:557). Vir hom gaan dit in 'n ordelike regering om drie sake, naamlik die owerheid wat wette maak, die wette self en die volk wat deur die wette regeer word.

Volgens Calvyn is die owerheid deur God ingestel en word dit beklee met 'goddelike gesag'. Hy beroep hom hiervoor op tekste soos Eksodus 22:8, Psalm 82:1, 6, Johannes 10:35, Deuteronomium 1:16 en 2 Kronieke 19:6. Wat vir hom egter veral belangrik is, is Romeine 13 waaruit dit duidelik blyk dat die owerheid 'n dienaar van God moet wees. Juis op grond van dié sienswyse moet die owerheid sy uitgangspunt kies in die 'religie' wat moet inhou dat hy nie net moet sorg vir die burgers en vir die regspraak nie, maar dat God ook suiwer gedien moet word. In die handhawing van reg en geregtigheid moet die goddeloses bestry word.

Die wette wat deur die owerheid gemaak word, moet rus op God se wet. Die wet van God moet die doel, grens en reël van alle wette wees (Calvyn, 1949:576). Die volk moet die owerheid eerbiedig en bereid wees tot diens; onderdane moet gehoorsaam wees aan alle regerings (Calvyn, 1949:586), maar die gehoorsaamheid aan die regering moet nie strydig wees met die gehoorsaaınheid aan God nie - gehoorsaamlieid aan God kom eerste. Volgens Calvyn mag die onderdaan ongehoorsaam wees aan die goddelose bevel van die koning. Vir hierdie uitgangspunt beroep Calvyn hom op Daniël 6:22, 1 Konings 12:30, Hosea 5:11 God moet meer gehoorsaam word as mense (Calvyn, 1949:595). Al hierdie beginsels in ag geneem, kies Calvyn (1949:564) vir die aristokratiese staatsvorm omdat 'n koningskap maklik tirannie kan word en 'n volksregering volksoproer.

Vir sy begronding van die taak van die owerheid leun Calvyn sterk aan teen die teokrasie van die Ou Testament en is sy bykans 200 preke uit Deuteronomium hiervoor rigtinggewend: Polman (s.j.:275) wys dit duidelik uit in sy bespreking van Calvyn se beskouing oor die taak van die owerheid. Min van die NuweTestamentiese riglyne kom egter in Calvyn se beskouing tereg. Dit is juis die OuTestamentiese gedeeltes wat Calvyn daartoe bring om te sê dat dit die owerheid geoorloof is om ketters te straf.

Calvyn se beskouing het sterk invloed uitgeoefen op die owerheidsbeskouing tydens die Reformasie. Beza en De Bres het hierop voortgebou (Polman, s.j.: 267). Ook Polyander (1625:310) het hom nagevolg, hoewel bogenoemde huiwerig was om ketters met die dood te straf. Feitlik al die Calvinistiese belydenisskrifte het hom daarin nagevolg, soos byvoorbeeld die eerste en tweede Confessio Helvetica, die Confessio Belgica, die Confessio Scotica en die Boheemse konfessie (Verkuyl, 1948:201). Sy beskouing oor die taak van die owerheid is voorts uitgedruk in artikel 23 van die invloedryke Westminster Confession van 1648 (Leith, 1982:20). Met inagneming van die bydraes van ander Reformatore kan die owerheidsbeskouing van daardie tyd in drie stellings saamgevat word. 
* Eerstens stel die vroee Calvinisme dit duidelik dat die skepsel en die owerheid die eer van die Here moet verhoog.

* Tweedens word beklemtoon dat die owerheid aan God se Woord en wet gebonde is en dit sluit albei tafels van die wet in.

* Derdens moet die andersheid en die selfstandigheid van die kerk en staat gehandhaaf word en die burgerlike en geestelike regering moet nie vermeng word nie. Daar moet wel voortdurende samewerking tussen kerk en owerheid bestaan: die een moet die ander tot hulp wees om die kwaad te weer.

Vir die owerheid moet God se eer en verheerliking die eerste plek inneem. Hierdie uitgangspunt vorm die grondslag van artikel 30 en 36 van die Nederlandse Geloofsbelydenis.

In Genève het Calvyn hierdie beginsels streng probeer toepas. In hierdie stadstaat onder beheer van Calvyn is 58 mense tereggestel en 76 verban vanweë kettery. Die bekendste hiervan was Servet wat in 1553 tereggestel is (Cairns, 1982: $311)$.

Hoe moet die bydrae van Calvyn dan geëvalueer word? Hy was ongetwyfeld 'n groot en invloedryke teoloog, maar moet soos enige ander teoloog en filosoof binne die konteks van sy tyd verstaan word. Polman (s.j.:274) en Verkuyl (1948: 199) meen dat Calvyn in sy beskouing van die owerheid deur die wysgerige tradisie van daardie tyd beïnvloed is. Die ou wysgere het reeds gesê dat die staat die godsdiens moet beskenn. Calvyn lees dit in die Skrif en kom tot die konklusie, veral uit Deuteronomium 13:6-11, dat dwepers wat 'n nuwe religie versin, die pousdom wil instel of die Koran wil invoer, gedood moet word.

'n Ander aspek binne die konteks van Calvyn se beskouing was dat die staatkunde as wetenskap nog nie ver ontwikkel was nie. Staatsvorme was hoofsaaklik sentraal-georiënteerde magstate waarin die fynere nuanses van demokrasie nie voorgekom het nie. Calvyn was ook primêr 'n teoloog en nie 'n staatkundige nie en sy keuse vir aristokrasie bewys sy aflanklikheid en onkritiese oomame van die sisteme wat in sy tyd bestaan het. Hy kon die magstaat maklik versoen met die teokrasie van die Ou Testament. Hierdie feit moet in gedagte gehou word in die beoordeling van Calvyn en ook van die vroeë formuleringe van artikel 36 van die Nederlandse Geloofsbelydenis.

\section{Enkele grepe uit die geskiedenis van artikel 36 van die Nederlandse Geloofsbelydenis}

De Bres het Calvyn se beskouing in artikel 36 van die Nederlandse Geloofsbelydenis weergegee. Tog was hierdie formulering reeds in daardie tyd 'n probleem. Benewens heftige kritiek van die Anabaptiste het Nicolae (1609:46) hier- 
die formulering gekritiseer. Hy het gestel dat die amp van die owerheid en die kerkdiens nie vermeng mag word nie, dat die owerheid nie wreedheid mag gebruik teen mense van ander godsdienste nie. Die owerheid moet eerder reg en geregtigheid gebied sodat die gemeente 'n rustige en stil lewe kan lei. Hy bring by implikasie ' $n$ klemverskuiwing wat in praktyk 'n groot wysiging is. Die owerheid moet nie direk die ander oortuiginge bestry nie, maar moet reg en orde handhaaf.

In sy baie goeie historiese uiteensetting van die kritiek op artikel 36 van die Nederlandse Geloofsbelydenis sedert die Reformasie wys Van der Merwe (1969: 5) daarop hoe soortgelyke wysiginge en klemverskuiwings aan die interpretasie van artikel 36 van die Nederlandse Geloofsbelydenis aangebring is deur die Savoy Declaration (1658), die Presbyterian Church (1729, 1787 en 1789) en die Associated Reformed Church in America (1799). Al hierdie verklarings lê klem op geen gewetensdwang en godsdiensuryheid met voorbehoude. In die volgende eeu is die gedeelte van die artikel wat lui dat die staat afgodery moet uitroei reeds weggelaat deur gereformeerde Kerke in Frankryk (1849 en 1872), in Genève (1848), in Neuchatel (1872), in Italië (1870) en in Waadland (1847).

In teenstelling met die beskouing van Calvyn het die Calvinisme ' $n$ positiewe sin vir godsdiensvryheid ontwikkel wat latere denke hieroor wesentlik beïnvloed het (Verkuyl, 1948:195). Dit is opmerklik dat hierdie wysiginge gepaard gegaan het met die ontwikkeling van die staatkunde en die opkoms van demokrasie met sy beklemtoning van die 'regstaat' teenoor die 'magstaat' (Hayes et al., 1962:489). In Christelike kringe het die begrip menseregte in 'n konkreet politieke sin ook in die agtiende eeu na vore begin kom as reaksie teen die verdrukkende outoritêre stelsels van daardie tyd (Stott, 1984:141).

Van besondere belang vir die ontwikkelinge in gereformeerde kringe in SuidAfrika is die ontwikkelinge sedert 1896 in die Gereformeerde Kerken in Nederland (GKN). Hierdie kerke in Nederland was in die eerste dekades van hierdie eeu die geestelike voedingsbron van die Calvinisme in Suid-Afrika wat op sy beurt die beleidbepaling van die owerheid sedert 1948 wesentlik beïnvloed het. Die bespreking van Polman (s.j. 290) en Van der Merwe (1969:4) hieroor is omvattend en goed gedokumenteer en hoef nie hier herhaal te word nie. Wat nodig is, is om uit hul afleidings die prinsipiele lyn saam te vat.

Die GKN waarsku teen 'n staatskerk of 'n staatsreligie, maar wil terselfdertyd nie die gedagte van 'n neutrale staat onderskryf nie. Hierdie standpuntinname berus op die Bybelse standpunt dat die owerheid ' $n$ instelling van God is. Oor die Konfessie word die belangrike uitspraak gemaak dat dit 'n historiese dokument is wat op 'n historiese wyse uitgelê moet word. Die konteks waarvan vroeër melding gemaak is, moet deeglik in berekening gebring word. Die belangrikste van alles is dat bevind word dat die Nuwe Testament nie die uitroeiing van ketters verkon- 
dig nie. In die lig hiervan het die GKN in 1905 besluit om die volgende gedeeite te skrap: " ... om alle afgodery en valse godsdiens teen te gaan en uit te roei, die ryk van die Antichris te vemietig". Verkuyl (1948:252) dui aan dat hierdie verandering op goeie eksegetiese gronde berus. Die saak is ook in 1949 by die Gereformeerde Ekumeniese Sinode (GES) beredeneer en dié liggaam het by alle lidkerke wat die Nederlandse Geloofsbelydenis as belydenis het, aanbeveel om die artikel so te wysig dat die formulering wat betrekking het op die direkte uitroei van afgode deur die owerheid weggelaat word. Na 1960 het die GKN ten opsigte van die gesag van die belydenis heeltemaal 'n ander weg opgegaan wat hier nie ter sprake is nie.

Die Gereformeerde Kerke in Suid-Afrika het heelwat later aan die saak aandag gegee na 'n beswaarskrif van Van der Merwe in 1967 en 1970 teen die Afrikaanse vertaling van artikel 36 van die Nederlandse Geloofsbelydenis (GKSA, 1973:191). Hy het beswaar aangeteken teen die stelwyse waarin om twee maal gebruik is omdat dit eintlik 'n viervoudige taak aan die owerheid toeken wat volgens hom nie in die tekste van Dordrecht gestel is nie. Hy was van mening dat die oorspronklike tekste slegs die tweërlei amp van die owerheid aandui, naamlik om te sorg vir die burgerlike regering en die hand te hou aan die kerkdiens.

Wat verder bygevoeg word, is nie ' $n$ verdere bepaling of uitbreiding van die amp nie, maar ' $n$ belydenis van die doel van die uitoefening van die tweërlei amp (GKSA, 1973:193).

Sy beswaar is gehandhaaf en ' $n$ nuwe vertaling is in 1979 aanvaar (GKSA, 1979: 478). Die hervertaling lui:

En dit is nie alleen hulle taak om aan die staatsbestuur aandag te gee en daaroor te waak nie, maar ook om die heilige woordbediening te beskerm, om sodoende alle afgodery en valse godsdiens teen te gaan en uit te roei, die ryk van die antichriste te vernietig en die koninkryk van Jesus Christus te bevorder, die Woord van die evangelie orals te laat verkondig, sodat God deur elkeen geëer en gedien word soos $\mathrm{Hy}$ in sy Woord beveel.

Hiervolgens is dit dus die taak van die owerheid om ruimte te skep vir die kerk om kerk te wees en vir die gelowiges om gelowige te wees. Ook in die Nederduitse Gereformeerde Kerk in Suid-Afrika is die artikel in 1958 gewysig (Dutch Reformed Church, 1986:19) en word die artikel in bogenoemde betekenis verklaar (Heyns, 1992:399). Afgodery moet dus op geestelike wyse deur die Woordbediening bestry word.

Dit is ' $\mathrm{n}$ vraag of die wysiging van artikel 36 van die Nederlandse Geloofsbelydenis deur die GKSA slegs ' $n$ hervertaling is. Heyns (1992:398) sê dit is 'n beter vertaling van die grondteks. 'n Soortgelyke standpunt is vroeër in Nederland deur Visscher gehandhaaf. Hy is egter deur Polman (s.j.:284) beskuldig van 
'n bisarre verklaring, wat berus op inlegkunde. Volgens hom stry die verklaring met die teks self en hy voer die Waalse teks van 1561 en die Nederlandse teks van 1562 as bewysplaas aan. Indien die inhoud van Calvyn en De Bres se beskouing beoordeel word, blyk dit dat Polman korrek is. Die nuwe vertaling is inderdaad ' $n$ inhoudelike wysiging en gee nie die bedoeling van die grondteks weer nie.

Die wysiging kan egter Skriftuurlik beter verantwoord word as die oorspronklike: die wysiging hou rekening met die teokrasie as kenmerk van Israel se regering van die Ou Testament en die feit dat die Nuwe Testament "geen enkele direkte uitspraak in soveel woorde oor die amp van die owerheid ten opsigte van die heilige kerkdiens, afgodery en valse godsdiens, die ryk van die antichris, die Koninkryk van Jesus Christus en die Woord van die Evangelie bevat nie" (GKSA, 1970:409). Voorts hou hierdie formulering rekening met die Bybelse beginsel dat die owerheid ' $n$ instelling van God is asook die subordineringsopdrag (Rom. 13:17). Eloff (1980:17) toon hierdie aspek duidelik aan.

\section{4. 'n Praktiese model vir godsdiensvryheid}

Die nuwe fonnulering van artikel 36 van die Nederlandse Geloofsbelydenis kan die menseregtebeginsel van godsdiensvryheid akkommodeer. 'n Staat wat etiesverantwoordelik handel, sal reg en orde handhaaf, menseregte bevorder en vrede bewaar (Heyns, 1988:135). Sodoende het die kerk en die gelowiges die vryheid om deur Woordverkondiging die koninkryk van God te bevorder. Godsdiensvryheid bied juis dié ruimte vir die owerheid, veral in lande waarin Christene die minderheid is.

Die essensiële vereiste van godsdiensvryheid is dat mense die reg moet hê om privaat en openlik, individueel en gemeenskaplik die godsdiens van hulle keuse ongehinderd te beoefen en uit te dra (Von Campenhausen, 1971:37). Die belangrikste terreine waarop die beginsel van godsdiensvryheid in 'n toekomstige SuidAfrika betrekking het, is die volgende: die aanhef van die grondwet, die openingsgebede by staatsgeleenthede, kapelaansdienste, onderwys en godsdiensuitsendings op staatsbeheerde media.

\subsection{Die aanhef van die grondwet}

Sedert 1910 met die vorming van die Unie van Suid-Afrika het die Suid-Afrikaanse grondwet 'n sogenaamde Christelike aanhef gehad waarin die hand van God in die lotgevalle van nasies erken is. Die aanhef het die toonaard van 'n openbare erkenning van God en van die volk se afhanklikheid van God. Die vraag ontstaan of so 'n erkenning en belydenis behoue moet bly in die lig van die teenwoordigheid van ander godsdienste in Suid-Afrika. 
Drie moontlikhede kan oorweeg word: die aanhef moet Christelik bly, die aanhef moet slegs 'n opperwese erken met wie elke godsdienstige groep hom kan vereenselwig, of die aanhef moet geskrap word. Om die aanhef as Christehke aanhef te behou, berus op die argument dat die wil van die meerderheid moet beslis. Die probleem van hierdie argument is dat meerderheidsbeslissing dan ook op ander terreine toegelaat moet word. Indien die Christene nie meer in die meerderheid is nie sou die reg dan ook bestaan dat ' $n$ nie-Christelike ideologiese vertrekpunt op meerderheidsgrondslag aanvaar kan word. Dit sou ook godsdiensstryd ontketen wat soos die geskiedenis bewys, tot fanatiese konflikte kan lei. 'n Owerheid het die taak om sulke stryd te voorkom.

Die argument dat die aanhef slegs 'n opperwese hoef te erken, word veral deur die World Conference of Religion and Peace - South Africa (WRPC-SA, 1992:3) gestel. Hulle voeg by dat die nasionale embleme, die vlag en monumente nie een spesifieke godsdiens moet bevorder nie. 'n Opperwese is 'n versoenbare begrip. Op grond van Deuteronomium 6:4 waarin die enigheid van God bely word, is so 'n standpunt vir Christene onaanvaarbaar. Die enigheid van God moet uitgedruk word in die objektiewe beskrywing van God en die subjektiewe ken van God Die Christene kan nie die Drie-enige God eien in 'n objektiewe godsbeeld nie, want dit impliseer dieselfde as die beeldediens wat in die tweede gebod verbied word (Eksodus 20:4). Voorts open die argument die deur vir godsdienssinkretisme wat op alle vlakke sal deurslaan, want as die aanhef 'n kompromie kan bevat, waarom nie ook die res van die godsdiensbelewing in die samelewing nie? Moet die godsdiensbelewing van die gemeenskap in sy geheel dan nie ook wentel om 'n Supreme Being nie?

Die argument dat die aanhef moet verval, het die meeste gewig. Die aanhef maak nie die konstitusie en gepaardgaande handves van menseregte Christelik nie. In die verlede het die Christelike aanhef nie apartheid of die sekularisasieproses gekeer nie. Bimne 'n land met 'n 'Christelike grondwet' vanweë sy Christelike aanhef is ' $n$ onchristelike beleid toegepas. Ook in die geskiedenis het Christelike formules as kwalifikasie van strukture nie 'n Christelike lewenswyse gewaarborg nie, soos Caims (1982:245) veral ten opsigte van die Corpus Christianum-ideaal van die laat Middeleeue aandui. Belangriker as ' $n$ Christelike aanhef tot die grondwet is 'n grondwet en gepaardgaande handves van menseregte wat inhoudelik uitdrukking gee aan Christelike, etiese beginsels soos die handhawing van reg, orde, vryheid, algemene moraliteit, beskerming van lewe, vryheid van spraak, versoening, vrye ekonomiese aktiwiteit en vrede. Die grondwet en die handves van menseregte moet in ooreenstemming met artikel 36 van die Nederlandse Geloofsbelydenis aan die Christen ruimte laat om Christen te wees en om sy Christelike oortuiging uit te dra. Die aanhef is nie so belangrik soos die inhoud nie en kan myns insiens verval. 


\subsection{Openingsgebede by staatsgeleenthede}

Op grond van 1 Timoteus 2:1-2 is voorbidding vir die owerheid ' $n$ baie belangrike beginsel in die gereformeerde etiek. Voorbidding impliseer nie slegs gebed vir die owerheid in die binnekamer of tydens die samekomste van Christene in eredienste nie, maar ook by staatsgeleenthede soos die parlementsitting, die instelling van ampsdraers en by vergaderings. So het die gebed ook tradisioneel in Suid-Afrika gefunksioneer. Hoe moet godsdiensvryheid in hierdie opsig geimplimenteer word?

Daar is verskeie standpunte hieroor. Die hedendaagse praktyk in 'n plurale godsdienstige gemeenskap is om een gebed tot ' $n$ Supreme Being te bid, deur een verteenwoordiger wat namens alle godsdienste bid. Elke godsdiens kan dan aan sy eie gebedsdeelname 'n eie inhoud verleen. Hierdie standpunt rus op die teologiese uitgangspunt dat alle godsdienste onderskeie openbaringe is van een god en as sodanig prinsipieel gelykwaardig en onderling aanvullend is. Chung (1991:3) het hierdie beskouing beklemtoon in haar opsienbarende lesing by die sitting van die Wêreldraad van Kerke in Canberra 1991. Vir Christene is so 'n standpunt onhoudbaar omdat dit die Christelike geloof van sy uniekheid beroof, en geensins rekening hou met die enigheid van God as sentrale gedagte in die Bybelse openbaringsgeskiedenis nie.

'n Ander standpunt is om afstand te doen van openbare gebede by staatsgeleenthede. Dreyer (1992:5) spreek hom ten gunste hiervan uit in sy reaksie op Kodesa 1 en 2. Ongelukkig bied hy daarvoor nie 'n Bybelse begronding nie. So 'n standpunt is eweneens vir Christene onhoudbaar, omdat dit die deur vir algehele sekularisasie open. Die logiese gevolg van hierdie standpunt is dat openbare gebede by alle ander openbare geleenthede soos skoolfunksies, kultuurverenigings en feeste om dieselfde redes nie moet plaasvind nie. Die standpunt bepleit by implikasie neutraliteit wat in stryd is met die kern van artikel 36 van die $\mathrm{Ne}$ derlandse Geloofsbelydenis.

Die beste oplossing sou waarskynlik wees om as volle konksekwensie van godsdiensvryheid, alle verteenwoordigende godsdienste geleentheid te gee vir godsdiensoefening. 'n Christen moet namens die Christene bid volgens Christelike oortuiging sonder enige druk op inhoudelike reduksie. Ander godsdienste kan dieselfde reg op enige wyse uitoefen. Op so 'n wyse kan die uniekheid van die Christelike geloof nie in die gedrang kom nie, word effektief uitvoering gegee aan 1 Timoteus 2:1-2 en vervul die Christen ook sy missionère roeping. Daarmee saam moet die belangrike mensereg van 'vryheid van assosiasie' uitgeoefen word - ' $n$ reg wat meebring dat niemand tot bywoning van ' $n$ godsdiensoefening buite sy keuse gedwing word nie. Die reëlings by Kodesa 1 en 2 blyk dus nog die beste model te wees waarop in die toekoms voortgebou kan word. 


\subsection{Kapelaansdienste}

Die deklarasie van die WRPC-SA (1992:2) bepleit die reg van elke godsdiens om kapelane in die Suid-Afrikaanse Weermag, Polisie en Korrektiewe dienste aan te stel. Hierdie kapelane moet toegang hê tot hulle eie 'lede' en oorlogsgevangenes. Hiermee word aangesluit by 'n gebruik wat reeds wêreldwyd bestaan. Daar word egter bygevoeg dat kapelane nie verplig moet word om militêre uniforms en wapens te dra of om 'n bepaalde ideologie te propageer en te bevorder nie.

Op die oog af lyk die bepaling na 'n konsekwente uitdrukking van godsdiensvryheid - tog hou dit vir Christene probleme in. 'n Owerheid kan van kapelane vereis om nie ' $n$ ideologie te verkondig wat die staat benadeel nie. Tussen dit wat die owerheid dan vra en die beperking op die bevordering van ' $n$ bepaalde ideologie, verval die kapelaansdiens in 'n onhoudbare neutraliteit. Die Christelike geloof ken geen neutraliteit in etiese beginsels nie. Voorts is die Christelike geloofsbeoefening veel meer as net kulties-religieuse handelinge - dit is lewensomvattend. Die diens van die kapelaan kan nie beperk word tot formele kultiese handelinge nie; hy moet die Woord bedien en sodoende die lewe van die Christen aanraak. Die Woordbediening bring hom dadelik by kontemporêre sake wat kan beteken dat hy in sy prinsipiële etiese standpuntstelling die beleid van die owerheid kan bevorder of benadeel.

Oorweging moet geskenk word aan die vraag of kapelaansdienste, gedra deur die staat, enigsins nodig is. Benewens die groot koste-aspek het dit 'n groot konflikpotensiaal in 'n toekomstige Suid-Afrika. Vir Christelike kerke is dit beter om lede van die Weennag, Polisie, Korrektiewe Dienste en gevangenes deur die onderskeie plaaslike kerke te laat bedien. Die plaaslike predikant en die kerkraad moet hierdie bediening soos alle ander bediening hanteer. Lidmate in die Veiligheidsdienste skakel by hulle kerke in soos met enige ander lidmaat die geval is. Die kerke moet binne gemeenteverband sorg dra dat die bediening voldoende is. So 'n reëling hou ook vir die owerheid kostebesparing in: die prinsipieel bedenklike praktyk dat die kapelaan as staatsamptenaar kerklike werk doen met die geld van die belastingbetaler word daanmee uitgeskakel. Die oplossing lê dus, myns insiens, daarin dat die Kapelaansdienste heeltemal afgeskaf word en dat die verskillende godsdienste toegelaat word om in dié opsig hulle lede op hulle eie manier te bedien.

In operasionele omstandighede sal ' $n$ kapelaansdiens wel nodig wees en kan dit in oorleg met Kerke gereël word. 'n Oorlog hef normale omstandighede op en in so 'n buitengewone situasie sal buitengewone reëlings nodig wees. Die buitengewone moet egter nie die reël word nie. 


\subsection{Onderwys}

Die toepassing van godsdiensvryheid ten opsigte van die onderwys op primêre, sekondêre en tersiêre vlak is een van die mees problematiese aspekte van die saak. In hierdie opsig moet onderskeid gemaak word tussen private onderwys en staatsonderwys.

Onder private onderwys word verstaan onderwys wat privaat, sonder staatsinmenging deur ouers van kinders of ander instansies in die private sektor bepaal, gereel en bedryf word. Gewoonlik het hierdie onderwys 'n lewens- en wêreldbeskoulike basis. Voorbeelde hiervan in die kerkgeskiedenis is volop en in feitlik alle Christelike lande bestaan die sogenaamde kerkskole of Christelike skole. Godsdiensvryheid bied aan hierdie skole geen bedreiging nie. Die onderwysinstelling het sy eie lewens- en wêreldbeskoulike basis en kan homself as sodanig identifiseer en bedryf. So byvoorbeeld kan Christelike privaatskole eksklusief Christelike beginsels propageer, die kinders daarin opvoed, en Bybelkunde kan vryelik aangebied word. Die erkenning van privaatskole noet bevorder word omdat dit ook aan godsdienste die reg bied on binne beginselraamwerk die opvoeding van die jeug waar te neem. Oorweging moet geskenk word aan staatsubsidiëring van behoeftige ouers wat dié soort onderwys verkies. Die instelling self moet egter nie gesubsidieer word nie, om sodoende onafhanklik te bly.

Die toepassing van godsdiensvryheid in staatskole skep meer probleme. Die deklarasie van die WRPC-SA bepleit dat staatskole

... should provide a multifaith education curriculum (religious studies) to foster respect for and appreciation of the various religions and worldviews. The decision to offer such a curriculum shall remain the choice of parents, teachers and the administration of each school (WRPC-SA, 1992:2).

Waar staatskole volgens die keuse van ouers godsdiensonderrig van ' $n$ bepaalde godsdiens vereis, bepleit die deklarasie ook die aanbied van parallelle onderrig vir ander godsdienste in dieselfde skool. Onderwysers moet hiervoor opgelei word en daar moet gewaak word teen 'proselietmakery' tussen godsdienste.

Benewens die vraag oor die praktiese uitvoerbaarheid van hierdie model, bring dit ook prinsipiële probleme na vore. Indien die meerderheid ouers besluit om 'Religieuse Studies' in die skool aan te bied, word daardeur tog ideologiese druk uitgeoefen op die minderheid wat nie daarmee saamgaan nie. Hierdie keuse bring ander menseregtebeginsels in gedrang - menseregtebeginsels soos vryheid van assosiasie en die verhindering van meerderheidsingrype in die godsdiensregte van die individu. Uit teologiese oogpunt beoordeel, berus hierdie Religious Studies ook op die godsdienssinkretisme waarvan vroeër melding gemaak is. Om hierin in te pas, sal die Christelike geloof gereduseer moet word tot 'n paar algemeen 
aanvaarbare 'godsdienstige waardes', wat nie aanstoot gee aan ander godsdienste nie.

Die tweede voorstel van die Deklarasie, naamlik dat die skool wat 'n sekere godsdiens se godsdiensonderrig verkies, ook parallelle kursusse vir ander verteenwoordigende godsdienste moet aanbied, lyk na 'n beter voorstel. Dit sou prakties beteken dat elkeen die reg het om die godsdiensonderrig van sy keuse te ontvang. Hierdeur sal die infrastruktuur van onderwys in staatskole egter onder groot druk kom en die vraag is of daar genoeg onderwysers sal wees wat op 'n kundige wyse die onderrig in verskillende godsdienste kan waarneem. Myns insiens kan die saak opgelos word deur byvoorbeeld aan kerke die geleentheid te bied om die Christelike godsdiensonderrig in skole waar te neem. Die plaaslike predikant kan dus die periode in Bybelkunde in die kurrikulum van die staatskool hanteer. Dieselfde reg kan toegeken word aan die ander godsdienste ten opsigte van hulle eie lede. Daannee saam moet beslag gegee word aan die beginsel van vryheid van assosiasie

\subsection{Godsdiensuitsendings op staatsbeheerde media}

Die Deklarasie van die WRPC-SA (1992:3) behandel hierdie saak in artikel 14. Die reg van elke godsdiens om inligting oor hulleself te versprei word bepleit met die byvoeging dat die inligting nie ander godsdienste moet afkam of wanvoorstel nie. In sy verdediging van hierdie standpunt pleit Kritzinger (1991:229) vir 'n "code of missionary conduct" wat moet verhoed dat godsdiente mekaar moet afkam en moet bydra tot 'n "wider ecumenism" waarin godsdienste nie vyande is nie, maar vennote. Hierdie beperking skep probleme. Uit juridiese oogpunt kan met reg gevra word of dit van die owerheid of die hof verwag kan word om waghond te speel oor die gehalte van inligting wat die godsdienste aanwend in die uitvoering van hulle onderskeie missionêre verpligtinge. Dit sou ook, teologies beskou, 'n ernstige reduksie meebring ten aansien van die sendingtaak van die Christelike geloof. Geloof in Christus as die enigste weg tot saligheid sal nie meer gepreek kan word nie. Dieselfde geld vir die oproep tot bekering. Op grond hiervan sou 'n predikant ook nie die afgodery van byvoorbeeld die Hindoeïsme kan afwys nie. Sou 'n kerkraad dan nog iemand kan tug oor afgodery? Indien hierdie deel van die Deklarasie in ' $n$ toekomstige handves van menseregte opgeneem word, kan sodanige tughandeling deur die hof ongeldig verklaar word. Die bepaling in artikel 14 van die Deklarasie is nie houdbaar nie en sal in die praktyk 'n verskraling van die Christelike geloof afdwing.

Met punt 14.2 van die deklarasie kan saamgestem word waar gepleit word vir die reg van toegang tot staatsbeheerde media op proporsionele basis. Ook hier moet egter gewaak word teen 'n reduksie van godsdienste om mekaar terwille te wees. 'n Predikant moet die volle reg hê om vryelik die inhoud van die geloofsleer te 
verkondig, openlik die Naam van die Drie-enige God aan te roep en te te bely en die Woord onbevange uit te dra. Dieselfde reg moet aan ander godsdienste gegee word.

Die versoek van die Deklarasie dat 'n gemeenskaplik 'godsdienstige advieslig, gaam' 'n adviesliggaam vir godsdiensuitsendings op die staatsbeheerde media moet aanwys, sal ook nie deug nie. Dit sou beteken dat die Christelike godsdiensuitsendings onder die ontleedmes staan van 'n adviserende liggaam wat nie die inhoud van die Christelike geloof verstaan of deel nie. Christene moet, myns insiens, 'n eie adviesliggaam hê wat deur die kerke, in samewerking daargestel word. Elke ander godsdiens kan dieselfde reg uitgoefen.

\section{Konklusie}

Godsdiensvryheid is 'n basiese mensereg wat deur die Christelike etiek terdeë erken word. Die toepassing daarvan mag egter nie 'n reduksie van die geloofsleer en die Bybelse openbaring meebring nie. Die ander belangrike reg van vryheid van assosiasie moet ook deurgaans gehandhaaf word. Dit blyk die beste weg te wees om aan Christene in alle aspekte van openbare godsdiensbeoefening die reg van volle geloofsbelewing en uitlewing toe te staan. Sodoende sal die owerheid sy taak volgens artikel 36 van die Nederlandse Geloofsbelydenis uitvoer, want deur die prediking en die openbare getuienis van gelowiges word afgodery bestry en op geestelike wyse word die koninkryk van God bevorder. Godsdiensvryheid is dan nie vir die Christene ' $n$ bedreiging nie, maar ' $n$ geleentheid waardeur die swaard van die Gees in die openbaar gehanteer word.

\section{Bibliografie}

CAIRNS, E.E 1982 Christianity through the Centuries Grand Rapids : Zondervan Publ. House.

CALVYN, J 1949. Institutie, of onderwijsing in de christelijke godsdienst Delft : W D Meinema.

CHUNG, HYUNG-KYUNG 1991. Come Holy Spirit, Renew the Whole Creation Geneve World Coucil of Churches

DREYER, P.S 1992. Die Christelike geloof en die neutrale staat Die Hervormer, 84(7) 5-7.

DUTCH REFORMED CHURCH 1986. This We Believe, This We Confess Doctrinal Standards of the Dutch Reformed Church. Johannesburg : DRC

ELOFF, T. 1980. Die taak van die owerheid in Rom. 13:1-7 Potchefstroom : PU vir CHO (Proefskrif - Th.D.)

GEREFORMEERDE EKUMENIESE SINODE 1983 RES Testimony on Human Rights Michigan : Grand Rapids, RES

GEREFORMEERDE KERKE IN SUID-AFRIKA 1970 Handelinge van die sewe en dertigste Sinodale vergadering van die Gereformeerde Kerke in Suid-Afrika Potchefstroom : Potch Herald.

GEREFORMEERDE KERKE IN SUID-AFRIKA. 1973. Handelinge van die agt en dertigste Sinodale vergadering van die Gereformeerde Kerke in Suid-Afrika Potchefstroom Potch Herald. 
GEREFORMEERDE KERKE IN SUID-AFRIKA 1976. Handelinge van die nege en dertigste Sinode van die Gereformeerde Kerk in Suid-Afrika, Potchefstroom, 14 Januarie 1976 e.v.d Potchefstroom : Potch Herald

GEREFORMEERDE KERKE IN SUID-AFRIKA 1979. Handelinge van die veertigste Sinode te Potchefstroom. Potchefstroom : Potch Herald.

GEREFORMEERDE KERKE IN SUID-AFRIKA 1985. Handelinge van die twee-enveertigste Nasionale Sinode. Potchefstroom : Potch Herald

\section{GKSA}

$k y k$

GEREFORMEERDE KERKE IN SUID-AFRIKA

HAYES, H.H.C., BALDWIN, M.W \& COLE, C W. 1962 A History of Western Civilization New York: The Macmillan Company

HEYNS, J.A. 1988. Teologiese Etiek. Deel 2/2. Pretoria : N.G Kerkboekhandel

HEYNS, J.A. 1992. Inleiding tot die Dogmatiek aan die hand van die Nederlandse Geloofsbelydenis Halfway House : N.G Kerkboekhandel

KRÄMER, P 1981 Religionsfreiheit in der Kirche Das Recht auf religiose Freiheit in der kirchlichen Rechtsordnung. Trier : Paulinus Verlag.

KRITZINGER, JN J 1991. A Contextual Christian Theology of Religions Missionalia, 19(3):215-231.

LEITH, J.H 1982 Creeds of the Churches A Reader in Christian Doctrine from the Bible to the Present Atlanta : John Knox Press

LENDVAI, P 1983 Religionsfreiheit und Menschenrechte Belang und Aussicht. Köln Verlag Styria

NEDERDUITS GEREFORMEERDE KERKE 1986 Church and Society A Testimony of the Dutch Reformed Church Bloemfontein Pro Christo Publishers

NICOLAE, I 1609 Grontlicke Onderwijsinghe teghen allerleye dwalinghen der Wederdooperen deses tijts in de Nederlanden. Franekerensem Rombertum Doyma (Bylaag by In die Skriflig, 3(11) 46-64 - 1969.)

POLMAN, ADR s.j. Onze Nederlandsche Geloofsbelijdenis. Verklaard uit het verleden Geconfronteerd met het heden Franeker : $T$ Wever.

POLYANDER, J e a 1625 Synopsis of overzicht van de Zuijverste Theologie, vol. 2 Enchede : J Boersma

RUNIA, K. 1990 The Gospel and Religious Pluralism Ecumenical Review of Theology, 14(4) $341-379$.

STOTT, J 1984. Issues Facing Christians Today Hants : Marshalls

SUID-AFRIKAANSE REGSKOMMISSIE 1991 Groeps- en menseregte Pretoria : Staats-drukker

VAN DER MERWE, D C S 1969 Die verandering van arikel 36 van die Nederlandse Geloofsbelydenis in Nederland in 1905: Progressie of regressie In die Skriflig, 3(11) 3-64.

VERKUYL, J 1948 Enkele aspecten van het probleem der godsdienstvrijheid in Azie Kampen J H Kok

VON CAMPENHAUSEN. AF 1971. Religionsfreiheit Gottingen Van den Hoeck und Ruprecht

WCRP

kyk

WORLD CONFERENCE OF RELIGION AND PEACE - SOUTH AFRICA 1990 Believers of the Future Cape Town: WCRP-SA

WORLD CONFERENCE OF RELIGION AND PEACE - SOUTH AFRICA. 1992. Draft Declaration on the Rights and Responsibilities of Religious People Pretoria : WCRPSA 
